\title{
Pengaruh Metode Pembelajaran Matematika Gasing Terhadap Hasil Belajar Matematika
}

\author{
Md Wahyu Kurniadhi Kusuma ${ }^{1}$, I Nyoman Jampel ${ }^{2}$, Gd Wira Bayu ${ }^{3}$ \\ ${ }^{13}$ Jurusan Pendidikan Guru Sekolah Dasar, FIP \\ ${ }^{2}$ Jurusan Teknologi Pendidikan, FIP \\ Universitas Pendidikan Ganesha \\ Singaraja, Indonesia \\ e-mail : wahyukusuma151@gmail.com ${ }^{1}$, jampel@undiksha.ac.id ${ }^{2}$, wira.bayu@undiksha.ac.id ${ }^{3}$
}

\begin{abstract}
Abstrak
Penelitian ini bertujuan untuk mengetahui perbedaan hasil belajar Matematika antara siswa kelas III yang mendapat perlakuan dengan metode pembelajaran Matematika GASING dan siswa kelas III yang tidak mendapat perlakuan dengan metode pembelajaran Matematika GASING. Jenis penelitian ini adalah penelitian eksperimen semu dengan rancangan nonequivalent posttest only control group design. Populasi penelitian ini adalah seluruh siswa kelas III SD di Gugus VIII Kecamatan Buleleng Kabupaten Buleleng Tahun Pelajaran 2017/2018 yang berjumlah 125 orang. Sampel diambil dengan cara random sampling yaitu siswa kelas III SD Negeri 1 Paket Agung dan siswa kelas III SD Negeri 2 Paket Agung. Data penelitian dikumpulkan menggunakan metode tes dalam bentuk uraian dengan instrumen tes hasil belajar Matematika. Data yang diperoleh dianalisis dengan menggunakan statistik deskriptif dan statistik inferensial (Uji-t). Hasil penelitian menunjukkan bahwa (1) skor rata-rata hasil belajar Matematika siswa kelas III yang mendapat perlakuan metode pembelajaran Matematika GASING adalah 15,71 yang berada pada kategori sangat tinggi, (2) skor rata-rata hasil belajar Matematika siswa kelas III yang tidak mendapat perlakuan motode pembelajaran Matematika GASING adalah 13,46 yang berada pada kategori tinggi, $(3)$ hasil analisis uji-t diperoleh $\left(F_{\text {hitung }}\right.$ $=2,237$ dengan sig $<\alpha(0,000<0,05)$ ini berarti bahwa terdapat perbedaan yang signifikan hasil belajar Matematika antara siswa kelas III yang mendapat perlakuan metode pembelajaran Matematika GASING dan siswa kelas III yang tidak mendapat perlakuan menggunakan metode pembelajaran Matematika GASING.
\end{abstract}

Kata-kata kunci: Metode GASING, hasil belajar, Matematika

\begin{abstract}
The aim of this research was to investigate the significant difference of Mathematic learning outcomes between students in third grade who got the treatment of GASING Mathematic learning method and the students who did not get the treatment of GASING method. The kind of this research was quasi experiment with non-equivalent posttest only control group design. The population of this research was all of the third grade students in Gugus VII Buleleng sub district Buleleng regency in year of 2017/2018 which amounted to 125 students. The samples were taken by using random sampling there were third grade students in SD Negeri 1 Paket Agung and SD Negeri 2 Paket Agung. The research data was collected by using test method in the form of a description with mathematics learning outcomes test instrument. The obtained data was analyzed by using descriptive statistics and inferential statistic (t-test). The result showed that (1) the average score of mathematic learning outcomes of third grade students who got treatment of GASING mathematic learning method was 15,71 that was in very high category (2) the average score of the learning outcomes of third grade students who did not get the treatment of GASING mathematic learning method was 13,46 which was in high category (3) the obtained result of $t$-test analysis was (Fcount $=2,237$ with sig $<\alpha(0,000<0,05)$ which means that there was significant difference of mathematic learning outcomes between students in third grade who got the treatment of GASING Mathematic learning method and the students who did not get the treatment of GASING mathematic learning method.
\end{abstract}

Keywords: GASING method, learning result, mathematics. 


\section{Pendahuluan}

Pendidikan merupakan suatu sistem yang terbangun dari beberapa komponen pendidikan yang satu dengan yang lain saling berhubungan. Sebagian masyarakat beranggapan bahwa kegagalan dan keberhasilan yang dialami oleh seseorang tergantung pada apa yang mereka dapatkan melalui persekolahan. Mereka lupa bahwa pendidikan tidak hanya persekolahan, melainkan banyak faktor yang turut menentukan, seperti tujuan pendidikan, pendidik, anak didik, lingkungan pendidikan, dan alat pendidikan. Keberhasilan dan kegagalan yang dialami oleh seseorang tidask hanya melalui pendidikan di sekolah, tetapi sasngat ditentukan oleh kerjasama antara faktor-faktor pendidikan itu (Saat, 2015).

Pasal 1 UU SISDIKNAS no. 20 tahun 2003 disebutkan bahwa Sistem Pendidikan Nasional adalah keseluruhan komponen pendidikan yang saling terkait secara terpadu untuk mencapai tujuan pendidikan nasional. Berangkat dari bunyi pasal ini dapat diketahui bahwa pendidikan adalah sistem yang merupakan suatu totalitas struktur yang terdiri dari komponen yang saling terkait dan secara bersama menuju kepada tercapainya tujuan (Soetarno, 2003: 2). Adapun komponen-komponen dalam pendidikan nasional antara lain adalah lingkungan, sarana-prasarana, sumberdaya, dan masyarakat. Komponen-komponen tersebut bekerja secara bersama-sama, saling terkait dan mendukung dalam mencapai tujuan pendidikan. Tujuan pendidikan nasional yang dirumuskan dalam UU SISDIKNAS adalah untuk mengembangkan potensi anak didik agar menjadi manusia yang beriman dan bertakwa kepada Tuhan Yang Maha Esa, berakhlak mulia, sehat, berilmu, cakap, kreatif, mandiri, dan menjadi warga Negara yang demokratis serta bertanggung jawab (Munirah, 2015).

Perkembangan ilmu pengetahuan dan teknologi (IPTEK) sangat berperan penting dan membantu dalam mengakses segala informasi dari berbagai negara di dunia. Kemajuan IPTEK pada saat ini tidak terlepas dari peran pendidikan.

Guru menjadi faktor yang menentukan mutu pendidikan karena guru berhadapan langsung dengan para peserta didik dalam proses pembelajaran di kelas. Di tangan guru, mutu dan kepribadian peserta didik dibentuk. Karena itu, perlu sosok guru kompeten, bertanggung jawab, terampil, dan berdedikasi tinggi. Guru adalah kurikulum berjalan. Sebaik apa kurikulum dan sistem pendidikan yang ada tanpa didukung oleh kemampuan guru, semuanya akan siasia. Guru berkompeten dan bertanggung jawab, utamanya dalam mengawal perkembangan peserta didik sampai ke suatu titik maksimal. Tujuan akhir seluruh proses pendampingan guru adalah tumbuhnya pribadi dewasa yang utuh (Shabir, 2015).

Untuk mengembangkan potensi diri dalam peserta didik agar menjadi manusia yang beriman dan bertakwa kepada Tuhan Yang Maha Esa, berakhlak mulia, sehat, berilmu, cakap, akif, mandiri dan menjadi warga Negara yang demokratis serta bertanggung jawab perlu adanya peningkatan mutu pendidkan khususnya pendidikan matematika. Untuk meningkatkan mutu pendidikan di Indonesia perlu adanya berbagai upaya yang harus di lakukan antara lain penyempurnaan kurikulum, perbaikan sistem pengajaran, peningkatan kualitas kemampuan guru, dan lain sebagainya. Banyak hal yang bisa dilakukan untuk mengatasi hal tersebut, salah satu nya adalah menciptakan suasana belajar yang baik, mengetahui kebiasaan kesenangan siswa agar suasana belajar dapat terkondisikan. Untuk itu, guru perlu meningkatkan mutu pembelajaran agar menjadi lebih baik, merancang rencana pembelajaran yang menarik dengan memperhatikan karakteristik siswa, materi yang diajarkan, dan sumber belajar yang tersedia. Dengan demikian, pendidikan yang dikehendaki dewasa ini adalah pendidikan yang berlangsung secara kontekstual. Pendidikan kontekstual dicirikan oleh proses pembelajaran yang diarahkan pada pemecahan masalah yang nyata, menghargai keberagaman individu, mendukung pembelajaran mandiri, menggunakan kelompok belajar secara kooperatif.

Menciptakan individu yang memiliki kompetensi handal merupakan tugas dari dunia pendidikan. Salah satu bidang ilmu dalam dunia pendidikan yang beperan dalam menciptakan individu yang memiliki kompetensi handal adalah matematika. Matematika merupakan bidang studi yang dipelajari oleh semua siswa dari sekolah dasar hingga sekolah menengah atas bahkan di perguruan tinggi. Matematika merupakan metode berpikir logis dengan cara sistematik, cermat, dan teliti yang dapat memberikan kegunaan praktis dalam kehidupan seharihari, karena banyak masalah dalam kehidupan sehari-hari yang membutuhkan pemecahan secara cermat dan teliti. Menurut Subarinah (dalam Yunart, \& Coesamin, 2013), menyatakan matematika merupakan ilmu pengetahuan yang mempelajarai struktur yang abstrak dan pola hubungan yang ada di dalamnya. Ini berarti belajar matematika dalam hakikatnya belajar konsep dan mencari hubungan antar konsep dan strukturnya. 
Pembelajaran matematika memiliki empat tujuan utama yaitu: (1) Memahami konsep matematika, menjelaskan keterkaitan antar konsep atau algoritma, secara luwes. (2) Mengembangkan aktivitas kreatif yang melibatkan imajinasi, intuisi, dan penemuan dengan mengembangkan pemikiran (3) Mengembangkan kemampuan pemecahan masalah, dan (4) Mengembangkan kemampuan menyampaikan imformasi. (Depdiknas, 2006). Berdasarkan tujuan diselenggarakanya pembelajaran matematika, hal penting yang harus diperhatikan adalah bahwa seorang guru harus merancang dan melaksanakan suatu pembelajaran yang memungkinkan siswa dapat secara aktif membangun pengetahuanya sendiri. Selain itu menurut Cornelius (dalam Leksa, Septiana, dkk, 2013), berpendapat bahwa perlunya siswa belajar matematika yaitu sebagai saran berpikir yang logis, sarana memecahkan masalah kehidupan sehari-hari, sarana mengenal hubungan pola-pola dan generalisasi pengalaman.

Namun demikian tidak dapat dipungkiri bahwa masih banyak siswa yang menganggap mata pelajaran matematika sulit, membosankan dan siswa cendrung jenuh dalam belajar. Hal ini dikarenakan siswa hanya menganggap belajar matematika berpatokan pada rumus-rumus yang ada di buku. Sehingga masalah ini dapat menimbulkan kesenjangan di dalam proses pembelajaran yang nantinya akan berpengaruh pada hasil belajar siswa. Hasil belajar merupakan suatu perubahan tingkah laku yang terjadi akibat adanya kegiatan interaksi belajar dan mengajar. Menurut Susanto (2013) hasil belajar merupakan perubahan-perubahan yang terjadi pada diri siswa, baik yang menyangkut aspek kognitif, afektif, dan psikomotorik sebagai hasil dari kegiatan belajar. Menurut Nurkancana \& Sunartana (dalam Suwartini \& Md. Tegeh, 2013) menyatakan bahwa hasil belajar merupakan hasil yang telah dicapai oleh pelajar setelah mengalami proses belajar dalam jangka waktu tertentu. Pengertian hasil belajar sebagaimana diuraikan di atas dipertegas lagi oleh Nawawi dalam Susanto (2013) yang menyatakan bahwa, hasil belajar dapat diartikan sebagai tingkat keberhasilan siswa dalam mempelajari materi pelajaran di sekolah yang dinyatakan dalam skor yang di proleh dari hasil tes mengenal sejumlah materi pelajaran tertentu.

Peneliti melihat lemahanya hasil belajar matematika siswa telah banyak menarik perhatian pendidik dan peneliti. Berdasarkan hasil pencatatan dokumen dengan guru kelas III di gugus VIII Kecamatan Buleleng, diketahui masih banyak siswa yang mendapatkan nilai di bawah KKM. Adapun rata-rata nilai yang di proleh hasil belajar matematika siswa di SD gugus VIII yaitu, hanya $27,2 \%$ siswa memproleh nilai di atas KKM sedangkan $72,8 \%$ siswa masih dibawah KKM. Tingginya mayoritas siswa mengalami kesulitan dalam menerima konsep matematika yang abstrak, sehingga mengakibatkan rendahnya minat siswa terhadap mata pelajaran matematika. Tugas seorang guru yaitu merancang pembelajaran yang interaktif, inspirakif, menyenangkan, menantang, memotivasi peserta didik untuk berpartisipasi aktif, serta dapat meningkatkan minat dan hasil belajar matematika siswa. Dalam hal ini, perlu di terapkanya suatu metode pembelajaran yang mampu memberikan kesempatan bagi siswa untuk aktif membangun pembelajaran berdasarkan pengalaman yang nyata.

Metode Pembalajaran Matematika GASING merupakan metode belajar dengan cara (gampang, asyik dan menyenangkan) memahami masalah secara langkah demi langkah untuk memproleh suatu capaian atau hasil. Surya \& Moss (dalam Prahmana \& Suwasti, 2014), menyatakan bahwa metode Matematika GASING memiliki bangunan dasar. Pertama bahwa tidak ada anak yang tidak bisa belajar matematika, hanya anak yang belum sempat mempelajari matematika dengan cara yang menyenangkan dan berarti. Kedua, matematika didasarkan pada pola dan pola ini membuat matematika bisa dimengerti. Ketiga, konteks visual terhadap konsep matematis harus datang sebelum notasi simbolis. Yang terakhir matematika bukanlah penghafalan, tapi mengetahui fakta dasar dengan pemahaman konseptual dan visual. (Wiyanti \& Wakhyuningsih, 2013) mendeskripsikan metode matematika GASING sebagai proses pembelajaran yang membuat siswa belajar easy, fun and enjoyable. Gampang (easy) dapat diartikan ketika siswa belajar, siswa dikenalkan dengan logika metematika yang mudah dipelajari dan diingat, Asyik (fun) berarti selama proses pembelajaran siswa mempunyai keinginan untuk belajar tanpa adanya paksaan, menyenangkan dapat diartikan adanya kepuasan dalam proses belajar karena penggunaan alat peraga dan permainan. (Shanty \& Wijaya, 2012) berpendapat, metode Matematika GASING merupakan proses belajar membuat siswa lebih mudah belajar, menyenangkan. Mudah artinya siswa diperkenalkan dengan logika matematika yaitu mudah dipelajari dan diingat. Kesenangan lebih mengarah pada pengaruh dari luar seperti alat bantu visual dan permainan. Kegiatan pembelajaran mengajar dengan menggunakan metode matematika gasing dirancang secara sistematik dan sistemik, dengan mengurutkan materi yang termudah sampai pada yang tersulit dengan tetap memperhatikan ketercapaian tujuan. (D Kolnel, dkk., 2015) berpendapat, metode Matematika GASING 
merupakan suatu cara belajar yang menyenangkan dengan menggunakan alat peraga, dan benda-benda yang ada dalam kehidupan sehari-hari sebagai pendukung dalam memahami suatu materi.

Menurut Ani \& Fitri (2013) Metode Pembelajaran Matematika Gasing terdiri dari lima tahap dalam proses pembelajaran yaitu: (1) Dialog sederhana. Dalam hal ini yang terlibat yaitu guru dan siswa, Guru memulai pembelajaran dengan berdialog secara sederhana dengan siswa seputar materi yang akan dipelajari. Dari dialog ini diharapkan siswa dapat memberikan pendapatnya, sehingga timbul hubungan yang erat antara S dan R. Sehingga apa yang menjadi tujuan yang di capai; (2) Berimajinasi dan berfantasi. Guru membantu siswa untuk berimajinasi mengenai kejadian-kejadian yang berhubungan dengan materi yang sedang dipelajari. Imajinasi penting karena dengan adanya imajinasi siswa akan melahirkan sebuah konsep, kreatifitas, inovasi dan prilaku yang aktual di dalam kehidupnya; (3) Menyajikan contoh soal yang relevan. Guru memberikan latihan berupa soal-soal sederhana yang hanya menggunakan formulasi matematika. Hal ini bertujuan untuk memperkuat penguasaan matematika siswa. Latihan atau training, merupakan suatu cara mengajar yang baik untuk menanamkan kebiasaan-kebiasaan tertentu. Cara ini juga dapat digunakan untuk memperoleh suatu ketangkasan, ketepatan, kesempatan dan keterampilan siswa dengan tujuan untuk memperkuat penguasaan matematika siswa; (4) Menyajikan materi secara mendalam. Guru memberikan makna fisis setelah siswa dirasa mampu mengerjakan semua soal-soal sederhana tadi. Pada tahap ini, siswa diharapkan mampu untuk mengetahui fenomena-fenomena apa saja yang di bahas dalam pembelajaran matematika yang telah dipelajari dengan memberikan makna pada setiap objek atau butir soal; (5) Memberikan variasi soal. Guru kembali memberikan soal namun yang lebih bervariasi, soal tersebut dapat berupa soal cerita. Memberikan varisasi soal pada pembelajaran matematika menggunakan metode matematika Gasing dapat meningkatkan kualitas pemahaman siswa, serta merangsang individu maupun kelompok dapat belajar dengan aktif. Kelima tahapan di atas, dapat memberi gambaran bahwa dengan menggunakan Metode Pembelajaran Matematika GASING ini mampu membuat belajar matematika menjadi lebih gampang, asyik dan menyenangkan, karena di dalam pembelajaran matematika tidak harus menghafalkan rumus matematika.

Menurut Suprijono (2012:5), hasil belajar adalah polapola perbuatan, nilai-nilai, pengertian-pengertian, sikapsikap, apresiasi dan keterampilan. Selanjutnya Supratiknya (2012: 5) mengemukakan bahwa hasil belajar yang menjadi objek penilaian kelas berupa kemampuankemampuan baru yang diperoleh siswa setelah mereka mengikuti proses belajar-mengajar tentang mata pelajaran tertentu. Dalam sistem pendidikan nasional rumusan tujuan pendidikan mengacu pada klasifikasi hasil belajar dari Bloom yang secara garis besar yaitu aspek kognitif, aspek afektif dan aspek psikomotor (Widodo, 2013).

Metode pembelajaran Matematika GASING memiliki Kelebihan dan kelemahan. Kelebihan metode pembelajaran Matematika GASING yaitu: (1) Membuat matematika menjadi lebih gampang, asyik dan menyenangkan karena dalam mengerjakan soal-soal matematika tidak harus menghafalkan rumus matematika; (2) Waktu yang digunakan lebih efektif dan efisien, karena apabila menggunakan rumus konvensional, soal-soal matematika umumnya baru dapat diselesaikan oleh siswa dalam waktu yang cukup lama. Tapi dengan metode GASING, siswa dapat menyelesaikan soal-soal dalam waktu relatif lebih cepat. Kekurangan metode pembelajaran Matematika GASING ini yaitu: (1) Pada saat ulangan berupa soal essai, jika siswa tidak menyertakan penghitungan dengan rumus, meski hasil jawabannya benar akan tetap dinyatakan salah; (2) Secara umum metode Gasing belum bisa diterapkan untuk menyelesaikan soal-soal matematika di perguruan tinggi, karena umumnya mahasiswa dituntut untuk bisa menurunkan berbagai rumus.

Berdasarkan hal tersebut, fokus permasalahan yang di cari dalam penelitian ini dapat dirumuskan sebagai berikut. Apakah terdapat perbedaan hasil belajar Matematika antara siswa kelas III yang mendapat perlakuan metode pembelajaran Matematika GASING dengan siswa kelas III yang tidak mendapat perlakuan metode pembelajaran Matematika GASING di GUGUS VIII Kecamatan Buleleng tahun pelajaran 2017/2018?

Pada akhirnya hasil kajian ini akan memberikan konfirmasi dalam proses pembelajaran diharapkan dapat menciptakan pembelajaran yang aktif, kreatif, dan inovatif, dan secara langsung akan memberikan pengalaman terhadap materi yang dipelajari, dan juga dapat meningkatkan kreatifitas guru dalam menggunakan berbagai ide dalam menerapkan model pembelajaran dengan baik dan benar. 


\section{Metode}

Jenis Penelitian yang digunakan pada penelitian ini adalah penelitian eksperimen semu (quasi exsperiment) dengan memberikan perlakuan (treatment) tertentu terhadap suatu subjek yang bersangkutan, dengan rancangan Post Test Only Control Group Design. Variabel penelitian ini terdiri atas (1) Variabel terikat (dependent) berupa hasil belajar yaitu post-test, dan (2) Variabel terikat (independent) berupa Metode Pembelajaran Matematika GASING.

Definisi operasional dalam penelitian ini antara lain: (1) Metode pembelajaran Matematika GASING; (2) Hasil belajar. Metode pembelajaran Matematika GASING adalah suatu cara belajar matematika secara gampang, sistemaik dan sistemik. Proses pembelajaran di lakukan langkah demi langkah dengan berbantuan alat peraga dan media nyata dalam kehidupan sehari-hari, dari materi yang termudah sampai pada yang tersulit, sehingga dapat memproleh suatu capaian atau hasil yang baik. Tahap-tahap pembelajaranya yaitu: (a) Guru memulai pembelajaran dengan berdialog secara sederhana dengan siswa seputar materi yang akan dipelajari; (b) Guru membantu siswa untuk berimajinasi mengenai kejadian-kejadian yang berhubungan dengan materi yang sedang dipelajari; (c) Guru memberikan latihan berupa soalsoal sederhana. Hal ini bertujuan untuk memperkuat penguasaan matematika siswa; (d) Guru memberikan makna fisis setelah siswa dirasa mampu mengerjakan semua soal-soal sederhana tadi; (e) Guru kembali memberikan soal namun yang lebih bervariasi.

Populasi dalam penelitian ini adalah seluruh siswa kelas III di Gugus VIII Kecamatan Buleleng tahun pelajaran 2017/2018. Di Gugus VIII Kecamatan Buleleng terdapat lima Sekolah Dasar yaitu: SD No. 1 Paket Agung, SD No. 2 Paket Agung, SD No. 1 Kendran, SD No. 1 Beratan, SD No. 2 Liligundi.

Dari kelima sekolah yang tergabung dalam Gugus VIII tersebut akan di pilih dua sekolah dijadikan sampel penelitian. Sebelum dipilih sebagai sampel penelitian ini, diuji terlebih dahulu untuk mengetahui tingkat kesetaraan kemampuan hasil belajar siswa. Untuk mengetahui kesetaraan kemampuan akademik siswa kelas III sekolah dasar di Gugus VIII Kecamatan Buleleng, maka peneliti menggunakan nilai hasil belajar Matematika semester I diuji kesetaraan dengan menggunakan analisis varian satu jalur (ANAVA A). Setelah di ketahui tingkat kesetaraanya dilanjutkan dengan melakukan pengundian. Pengambilan sampel menggunakan teknik random sampling yaitu simple random sampling. Penarikan sampel sederhana ini nantinya akan membuat semua subjek mendapat hak yang sama untuk memperoleh kesempatan dipilih menjadi anggota sampel (Agung, 2014). Untuk menentukan pilihan sampel penelitian. Yang di jadikan sampel dalam penelitian ini adalah SD No. 1 Paket Agung sebagai kelas eksperimen yang diberikan perlakuan dengan menggunakan Metode Pembelajaran Matematika GASING, dan SD No. 2 Paket Agung sebagai kelas kontrol tidak diberikan perlakuan Metode Pembelajaran Matematika GASING.

Instrumen pengumpulan data menggunakan tes berupa tes uraian hasil belajar Matematika. Sebelum instrument penelitian digunakan terlebih dahulu tes uji secara empiris unutk mengetahui validitas, reliabilitas, daya beda, dan indeks kesukaran tes di kelas IV SD Negeri 3 Sukasada. Berdasarkan hasil analisis uji coba tes dari 12 butir soal didapatkan 10 butir soal yang valid sedangkan 2 soal dinyatakan tidak valid. Butir tes yang valid akan digunakan sebagai post-test. Berdasarkan uji reliabilitas tes, diproleh koefisien reliabilitas pada soal uji coba sebesar 0,71 . Hal ini di nyatakan kriteria soal tinggi. Hasil uji daya beda pada soal uji coba terdapat 5 butir soal tergolong cukup baik dan 5 butir soal tergolong kurang baik. Indeks tingkat kesukaran dari tes uji coba yang dilakukan terdapat 9 butir soal tergolong mudah dan 1 butir soal tergolong sedang. Berdasarkan analisis dari keseluruhan tes yang di lakukan dapat di simpulkan dari 12 butir soal terdapat 10 soal yang di myatakan dapat di gunakan sebagai posttest sedangkan 2 soal dinyatakan gugur.

Teknik analisis dalam penelitian ini yaitu statistik deskriptif dan statistik inferensial (uji-t). Sebelum dilakukanya uji analisis data terlebih dahulu dilakukanya uji prasyarat analisis meliputi uji normalitas dan uji homogenitas varians. 


\section{Hasil dan Pembahasan}

Tabel 1. Hasil Perhitungan Statistik Deskriptif Skor Hasil Belajar Matematika

\begin{tabular}{ccc}
\hline Data Statistik & \multicolumn{2}{c}{ Hasil Belajar Matematika } \\
& Kelompok Eksperimen & Kelompok Kontrol \\
\hline Mean & 15,71 & 13,46 \\
Median & 16,00 & 13.00 \\
Modo & 17 & 12 \\
Std. deviation & 2,581 & 2,026 \\
Variance & 6,662 & 4,105 \\
\hline
\end{tabular}

Berdasarkan Tabel 1 diketahui bahwa pada kelas eksperimen ( $\mathrm{Mo}=17>\mathrm{Md}$ $=16,00>M=15,71)$. Sedangkan pada kelas kontrol $(M o=12<M d=13,00<M=13,46)$. Data hasil belajar matematika pada kelompok eksperimen dalam bentuk poligon dapat dilihat pada Gambar 1

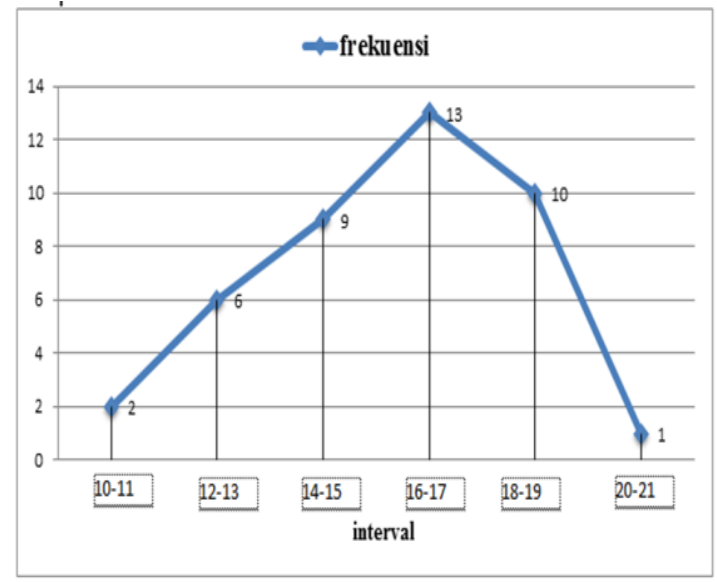

Gambar 1. Kurva Poligon Hasil Belajar Matematika Kelas Eksperimen.

Berdasarkan Gambar 1 menunjukkan bahwa data kelas eksperimen merupakan kurva juling negatif yang berarti sebagian besar skor hasil belajar matematika siswa cenderung sangat tinggi. Kecenderungan skor ini dapat dibuktikan dengan melihat frekuensi relatif pada tabel distribusi frekuensi. Frekuensi relatif skor yang berada di atas rata-rata lebih besar dibandingkan frekuensi relatif skor yang berada di bawah rata-rata.

Data hasil belajar kelompok kontrol dalam bentuk poligon dapat dilihat pada gambar 2

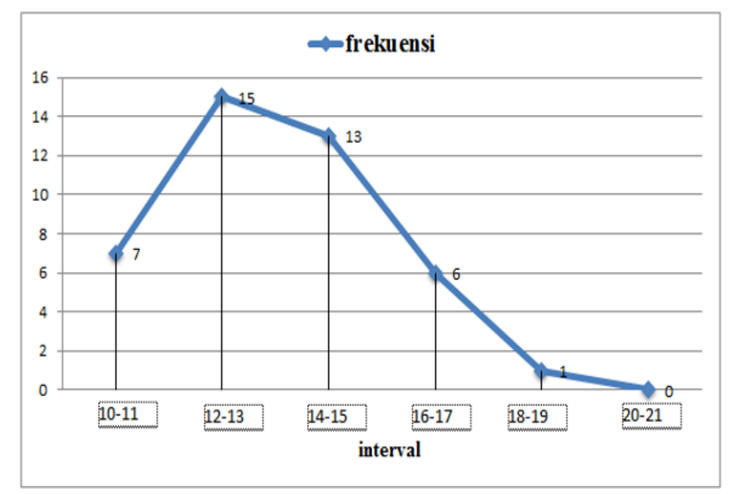

Gambar 2. Kurva Poligon Hasil Belajar Matematika Kelas Kontrol

Berdasarkan hasil perhitungan rata-rata hasil belajar matematika kelas kontrol adalah 13,46 lebih kecil dari rata-rata hasil belajar matematika kelas eksperimen sebesar 15,71. 
Hasil deskripsi data baik kelas kontrol dan eksperimen akan diuji hipotesis dengan menggunakan analisis Uji-t. Namun sebelum dilakukan uji hipotesis, data penelitian akan diuji prasyarat untuk mengetahui apakah data berdistribusi normal atau tidak serta homogeny atau tidak.

Setelah dilakukanya uji prasyarat dengan menggunakan program SPSS PC 17.0 for Windows, data yang diproleh telah memenuhi persyaratan normalitas, homogenitas varians, menunjukan bahwa data berdistribusi normal dan varians kedua kelopok homogen. Dengan demikian pengujian statistik hipotesis dapat di lakukan. Rangkuman hasil perhitungan uji-t antar kelompok eksperimen dan kelompok kontrol disajikan dalam tabel 2 ,

Tabel 2. Hasil Uji Hipotesis

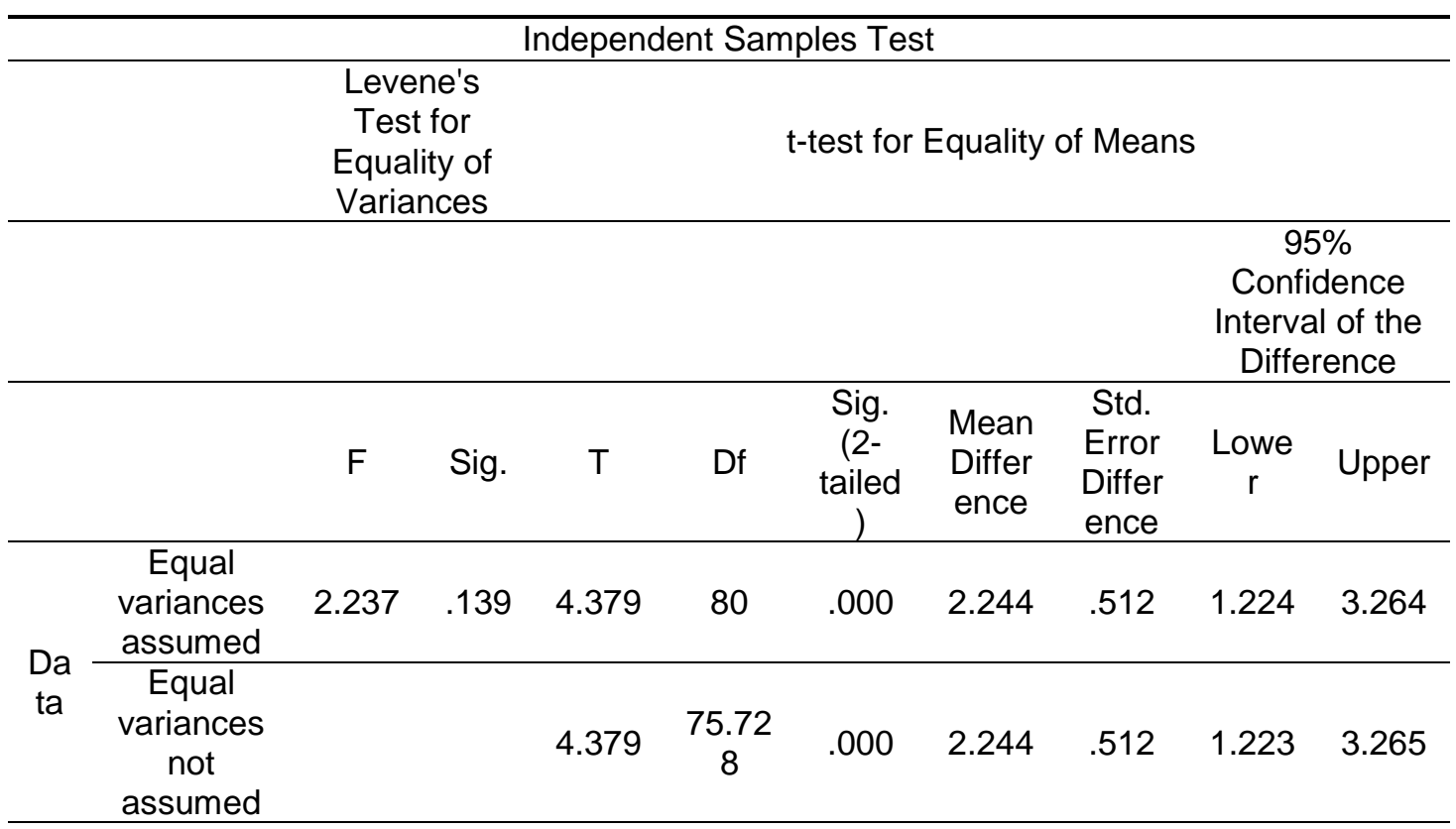

Dari hasil perhitungan pada Tabel 2 menunjukkan bahwa, nilai T yang diperoleh sebesar 4,379 dengan taraf signifikansi 0,000. Signifikansi nilai T tersebut menunjukkan bahwa, terdapat perbedaan hasil belajar antara kelas eksperimen dan kelas kontrol.

Dengan demikian, dapat disimpulkan bahwa terdapat Pengaruh Metode Pembelajaran Matematika GASING Terhadap Hasil Belajar Matematika Siswa Kelas III Sekolah Dasar Gugus VIII Kecamatan Buleleng Kabupaten Buleleng Tahun Pelajaran 2017/2018.

Berdasarkan data hasil analisis penelitian yang di lakukan, kelompok siswa yang mengikuti pembelajaran dengan metode pembelajaran Matematika GASING memiliki hasil belajar yang lebih tinggi dnengan nilai rata-rata 15,71 berada dalam kategori sangat tinggi, sedangkan kelompok siswa yang tidak mengikuti pembelajaran dengan metode pembelajaran Matematika GASING memproleh nilai rata-rata 13,46 dalam kategori sedang. Secara deskriptif, hasil belajar matematika siswa kelompok eksperimen lebih tinggi dibandingkan dengan siswa kelompok kontrol. Hal ini didasarkan pada rata-rata skor hasil belajar matematika. Rata-rata skor hasil belajar matematika siswa kelompok eksperimen berada pada kategori sangat tinggi sedangkan skor hasil belajar matematika siswa kelompok kontrol berada pada kategori tinggi. Berdasarkan análisis data menggunakan uji-t, diperoleh nilai $T$ sebesar 4,379 dengan taraf signifikansi sebesar 0,000 kurang dari 0,05. Dengan demikian diproleh keterangn terdapat perbedaan yang signifikan hasil belajar matematika, antara siswa yang mengikuti pembelajaran menggunakan metode pembelajaran Matematika GASING dengan siswa yang mengikuti pembelajaran menggunakan metode bukan pembelajaran Matematika GASING. Perbedaan yang signifikan tersebut, disebabkan karena pembelajaran menggunakan metode Matematika GASING lebih mengarahkan siswa kepada hal-hal yang konkret untuk memahami suatu konsep materi yang di ajarkan. Metode pembelajaran Matematika GASING merupakan suatu metode yang menekankan siswa agar belajar menjadi gampang, asyik dan menyenangkan. Sehingga dalam pembelajaran matematika, siswa tidak hanya mengacu pada rumus-rumus yang diberikan oleh guru, melainkan dengan menggunakan benda atau alat peraga yang bersifat nyata. Hal ini didukung oleh Prahmana \& Suwasti (2014) menyatakan bahwa metode 
Matematika GASING memiliki bangunan dasar. Pertama, tidak ada anak yang tidak bisa belajar matematika, hanya anak yang belum sempat belajar matematika dengan cara yang menyenangkan dan berarti. Kedua, matematika didasarkan pada pola dan pola ini membuat matematika bisa dimengerti. Ketiga, konteks visual terhadap konsep matematis harus datang sebelum nitasi simbolis. Yang terakhir matematika bukanlah penghafalan tetapi mengetahui fakta dasar dengan pemahaman konseptual dan visual. Menurut Ani \& fitri (2013) metode pembelajaran Matematika GASING dalam penerapanya didalam kelas menuntut siswa untuk, melakukan dialog sederhana, berimajinasi atau berfantasi, mengerjakan contoh-contoh soal yang relevan, mempelajari materi secara mendalam, kemudian yang terakhir melatih variasi soal yang diberikan. Hal ini dapat memberdayakan kemampuan siswa dalam pembelajaran matematika dan mengembangkan kegiatan pembelajaran menjadi berpusat kepada siswa serta siswa juga menjadi aktif baik dalam individu maupun kelompok.

Kelebihan metode pembelajaran Matematika GASING ini Membuat matematika menjadi lebih gampang, asyik dan menyenangkan karena dalam mengerjakan soal-soal matematika tidak harus menghafalkan rumus matematika. Waktu yang digunakan lebih efektif dan efisien, karena apabila menggunakan rumus konvensional, soal-soal matematika umumnya baru dapat diselesaikan oleh siswa dalam waktu yang cukup lama. Tapi dengan metode pembelajaran GASING, siswa dapat menyelesaikan soal-soal dalam waktu relatif lebih cepat.

Hasil penelitian ini sejalan dengan hasil penelitian yang dilakukan oleh (Yani \& Widuri, 2016) Hasil penelitian yang menunjukan peningkatan hasil belajar matrikulasi pada perkalian bilangan bulat setelah diterapkanya metode Matematika GASING. Penelitian dilakukan oleh (Wildan \& Trissiana, 2016) Berdasarkan hasil penelitian yang dilakukan pada siswa diperoleh peningkatan hasil belajar matematika setelah di terapkan pembelajaran matematika GASING.

Berbeda halnya dengan pembelajaran pada kelas kontrol, proses pembelajaran berlangsung kurang optimal. Selama proses pembelajaran siswa terlihat pasif. Kegiatan permainan akademik belum dikembangkan dalam pembelajaran. Meskipun siswa sudah di tugaskan untuk mempelajari materi, tapi hal itu tidak menjamin siswa akan benar-benar paham akan materi yang di pelajari. Siswa hanya menerima penjelasan materi dari guru. Materi yang dijelaskan guru hanya menjadi bahan hafalan bagi siswa sehingga pemahaman konsep siswa masih rendah.

\section{Simpulan dan Saran}

Berdasarkan hasil penelitian dan pembahasan di atas, dapat disimpulkan sebagai berikut. (1) Hasil belajar matematika siswa pada kelas kontrol berada pada katagori tinggi dengan rata-rata skor 13,46 . Jika dikonversikan dalam grafik polygon, kurve sebaran datanya adalah juling positif, yang artinya sebagian besar skor yang diperoleh siswa cenderung rendah; (2) Hasil belajar matematika siswa pada kelompok eksperimen setelah menerapkan metode Pembelajaran Matematika GASING berada pada katagori sangat tinggi dengan rata-rata skor 15,71. Jika dikonversikan dalam grafik polygon, kurve sebaran datanya adalah juling negatif, yang artinya sebagian besar skor yang diperoleh siswa cenderung sangat tinggi; (3) Terdapat perbedaan yang signifikan hasil belajar matematika antara kelompok siswa yang dibelajarkan dengan menggunakan metode pemebelajaran Matematika GASING dan kelompok siswa yang tidak dibelajarkan dengan menggunakan metode pembelajaran Matematika GASING pada siswa kelas III SD Gugus VIII kecamatan buleleng tahun pelajaran 2017/2018. Hasil ini peroleh berdasarkan analisis inferensial uji-t menggunakan SPSS PC 17.0 for Windows diperoleh nilai $t$ dengan df 80 sebesar 4,379 dan nilai signifikansi 0,000 . Hasil analisis menunjukkan bahwa angka signifikansi (sig) lebih kecil dari $\alpha$ yaitu $0.000<0.05$ sehingga $\mathrm{H}_{0}$ ditolak dan $\mathrm{H}_{1}$ diterima.

Adapun beberapa saran yang dapat disampaikan berdasarkan penelitian yang dilakukan yaitu: (1) Kepada siswa, dengan diterapkannya strategi pembelajaran REACT agar mengikuti langkah-langkah pembelajaran dengan baik, sehingga mampu meningkatkan hasil belajar matematika; (2) Disarankan kepada guru-guru di sekolah dasar gugus VIII Kecamatan Buleleng, agar dapat menciptakan suasana pembelajaran yang inovatif dengan menerapkan metode pembelajaran yang lebih inovatif, seperti metode pembelajaran Matematika GASING. Agar siswa lebih senang dalam belajar dan dapat meningkatkan hasil belajar siswa; (3) Disarankan bagi kepala sekolah untuk dapat menerapkan metode pembelajaran Matematika GASING untuk meningkatkan hasil belajar matematika; (4) Disarankan kepada peneliti lain yang berminat untuk mengadakan penelitian lebih lanjut tentang metode pembelajaran Matematika GASING agar memperhatikan kendala-kendala yang dialami dalam penelitian ini 
sebagai bahan pertimbangan untuk perbaikan dan penyempurnaan penelitian yang akan dilaksanakan.

\section{Daftar Pustaka}

Agung, A. A. Gede. 2014. Metodologi Penelitian Pendidikan. Yogyakarta: Aditya Media Publishing.

Ani, Fitri. 2013. "Metode Pembelajaran Gasing" Tersedia pada https://www.scribd.com/document/130406756/Metode-Pembelajaran-Gasing. (Diakses tanggal 20/11/2017).

D Kolnel, R. P., Charitas Indra Prahmana, R., Arifin, S., Kunci, K., Matematika GASING, P., Belajar Siswa, H., ... Surya, S. (2015). "Pengaruh Pembelajaran Matematika GASING Pada Materi Geometri Terhadap Hasil Belajar Siswa Kelas VII Sekolah Menengah Pertama." Pengaruh Pembelajaran.... Volume II. Nomor, 1. Tersedia pada https://www.researchgate.net/profile/Rully_Prahmana/publication/27980432. (Diakses tanggal 05/12/2017).

Leksa, K., Septiana, D., Japa, I. G. N., Wibawa, I. C., \& Pgsd, J. 2013. "Pengaruh Model Pembelajaran Game of Question Cards Terhadap Hasil Belajar Matematika Siswa Kelas Iv Sddi Desa Joanyar". Tersedia pada https://ejournal.undiksha.ac.id/index.php/JJPGSD/article/view/808/681. (Diakses tanggal 10/12/2017).

Munirah. 2015. Sistem Pendidikan Di Indonesia: Antara Keinginan Dan Realita . Jurnal AULADUNA, VOL. 2 NO. 2 DESEMBER 2015: 233-245

Ningsih, W., Yunart, T., \& Coesamin, M. 2013. "Pengaruh Penerapan Model Pembelajaran Kooperatif Tipe Numbered Head Together (NHT) Terhadap Hasil Belajar Matematika Siswa". Jurnal Pendidikan Matematika, 2(1), 17-22. Tersedia pada http://ojs.uho.ac.id/index.php/JPPM/article/view/3055/2292. (Diakses tanggal 10/12/2017)

Peraturan Menteri Pendidikan Nasional Republik Indonesia Nomor 22 Tahun 2006 Tentang Standar isi. Tersedia pada http://www.aidsindonesia.or.id/uploads/20130729141205.Permendiknas_No_22_Th_2006. pdf. (Diakses tanggal 17/11/2017).

Prahmana, R. C. I., \& Suwasti, P. 2014. "Local instruction theory on division in mathematics gasing: the case of rural area's student in indonesia. IndoMS-JME, 5(1), 2014". Tersedia pada http://ejournal.unsri.ac.id/index.php/jme/article/view/1445/522. (Diakses tanggal 05/12/2017).

Susanto, Ahmad. 2013. Teori Belajar dan Pembelajaran di Sekolah Dasar. Jakarta: Kencana Prenadamedia.

Shanty, N. O., \& Wijaya, S. 2012. "Rectangular Array Model Supporting Students' Spatial Structuring in Learning Multiplication". Indonesian Mathematical Society Journal on Mathematics Education, 3(2), 175-186. Tersedia pada http://eric.ed.gov/?q=\%2Btitle\%3Aarrays+3D+dimensional+cube\&id=EJ1078596\%0Afiles/2 927/Shanty and Wijaya - 2012 - Rectangular Array Model Supporting Students' Spati.pdf\%0Afiles/2928/eric.ed.gov.html. (Diakses tanggal 05/12/2017).

Saat, Sulaiman. 2015. Faktor-Faktor Determinan Dalam Pendidikan (Studi Tentang Makna Dan Kedudukannya Dalam Pendidikan) . Jurnal Al-Ta'dib Vol. 8 No. 2, Juli-Desember 2015

Suwartini, Md. Tegeh, N. K. S. 2013. "Pengaruh Model Pembelajaran Matematika Realistik Matematika Kelas V SD DI Gugus III". Tersedia pada 
https://ejournal.undiksha.ac.id/index.php/JJPGSD/article/view/912. (Diakses tanggal 06/12/2017).

Shabir, M. 2015. Kedudukan Guru Sebagai Pendidik: (Tugas Dan Tanggung Jawab, Hak Dan Kewajiban, Dan Kompetensi Guru) . Jurnal Auladuna, Vol. 2 No. 2 Desember 2015: 221 232

Widodo. 2017. Peningkatan Aktivitas Belajar Dan Hasil Belajar Siswa Dengan Metode Problem Based Learning Pada Siswa Kelas Viia Mts Negeri Donomulyo Kulon Progo Tahun Pelajaran 2012/2013 . Jurnal Fisika Indonesia No: 49, Vol XVII, Edisi April 2013 ISSN : 1410-2994

Wiyanti, W., \& Wakhyuningsih, N. 2013. "Penerapan Matematika GASING (Gampang, ASylk, menyenaNGkan) pada Materi Penjumlahan Dua Digit dengan Dua Digit untuk Siswa Kelas 1 Sekolah". Proc. National Congress on. Tersedia pada http://www.academia.edu/download/32056105/Matematika_GASING.pdf. (Diakses tanggal 05/12/2017).

Wildan, D. N., \& Trissiana, O. 2016. "Peningkatan Kemampuan Pemahaman Matematis Siswa Menggunakan Pembelajaran Matematika GASING, 2(1). Tersedia Pada http://ejournal.hamzanwadi.ac.id/index.php/jel/article/view/152. (Diakses tanggal 05/12/2017). 